\title{
Stock enhancement by hatchery-released turbot, Psetta maxima, in the southeastern Black Sea: capture, migration, growth and diet analyses
}

\author{
Orhan Ak ${ }^{1}$, Binnur Ceylan ${ }^{2}$, İlhan Aydin ${ }^{1}$, Hamza Polat ${ }^{1}$, Ercan Küçük ${ }^{1}$, Oğuzhan Eroğlu ${ }^{1}$, \\ Kostas Kapiris $^{3}$ \\ ${ }^{1}$ Central Fisheries Research Institute, Trabzon, Turkey. E-mail: orhan.ak@tarim.gov.tr \\ ${ }^{2}$ General Directorates of Fisheries and Aquaculture, Ankara, Turkey. \\ ${ }^{3}$ Hellenic Centre for Marine Research, Institute of Marine Biological Resources and Inland Waters, Greece.
}

\begin{abstract}
Summary: In this study, the capture, growth, migration and diet of hatchery-released turbots (Psetta maxima) were examined in the southeastern Black Sea region for six years (2009-2014). A total of 9933 turbots were marked with individual serialnumbered T-bar anchor tags and released at Trabzon, Turkey. The mean TL and weight of the released turbots were $12.91 \mathrm{~cm}$ $( \pm 1.25)$ and $35.41 \mathrm{~g}( \pm 12.38)$ and the same measurements for the captured turbots were $31.17 \pm 0.86 \mathrm{~cm}$ and $878.08 \pm 69.47 \mathrm{~g}$, respectively. A total of $2.7 \%$ (270 fishes) of the tagged individuals were captured during the study period and the age of the captured tagged fishes was between $0^{+}$and $5^{+}$years. Growth of the captured turbots was analytically examined. Movements of the tagged turbots were expressed as "resident" and "migratory". Three prey groups showed the majority of forage organisms; teleost fishes, crustaceans and mollusks in the stomach of the captured turbots. The hatchery-released turbots might be used for stock enhancement due to their high growth rate and commercial value, and their relatively limited migration range.
\end{abstract}

Keywords: turbot; stock enhancement; tagged; capture; growth; migration; feeding; Black Sea.

Mejora de stocks en el sudeste del Mar Negro, mediante la liberación de rodaballos, Psetta maxima, criados en cautividad: análisis de la captura, migración, crecimiento y dieta

Resumen: En este estudio se examinaron datos de captura, crecimiento, migración y dieta, de rodaballos (Psetta maxima) criados en cautividad y liberados en zonas del sudeste del Mar Negro, durante seis años (2009-2014). Se marcaron individualmente un total de 9933 rodaballos, utilizando marcas numeradas en serie (marcas de plástico tipo T) y se liberaron en Trabzon (Turquía). Las medias de longitud total (TL) y peso total de los rodaballos liberados fueron de $12.91 \mathrm{~cm}( \pm 1.25)$ y $35.41 \mathrm{~g}$ $( \pm 12.38)$, y las mismas medidas para los rodaballos capturados fueron de $31.17 \pm 0.86 \mathrm{~cm}$ y $878.08 \pm 69.47 \mathrm{~g}$, respectivamente. Un $2.7 \%$ (270 peces) de los individuos marcados fue capturado durante el periodo de estudio y la edad de estos individuos osciló entre $0^{+}$y $5^{+}$años de edad. El crecimiento de los rodaballos capturados se examinó analíticamente. Los movimientos de los rodaballos marcados fueron expresados como "residentes" y "migratorios". La mayoría de los organismos presentes en los estómagos de los rodaballos capturados pertenecían a tres grupos de presas: peces teleósteos, crustáceos y moluscos. Los rodaballos criados en cautividad y liberados podrían ser usados en la mejora de stocks debido a su elevada tasa de crecimiento, valor comercial, y su relativamente limitado rango de migración.

Palabras clave: rodaballo; mejora de stocks; marcaje; captura; crecimiento; migración; alimentación; Mar Negro.

Citation/Como citar este artículo: Ak O., Ceylan B., Aydin I., Polat H., Küçük E., Eroğlu O., Kapiris K. 2016. Stock enhancement by hatchery-released turbot, Psetta maxima, in the southeastern Black Sea: capture, migration, growth and diet analyses. Sci. Mar. 80(2): 163-174. doi: http://dx.doi.org/10.3989/scimar.04324.25A

Editor: E. Mañanos.

Received: July 29, 2015. Accepted: April 11, 2016. Published: May 28, 2016.

Copyright: () 2016 CSIC. This is an open-access article distributed under the Creative Commons Attribution-Non Commercial Lisence (by-nc) Spain 3.0.

\section{INTRODUCTION}

Release of the cultivated species should be added to efficient management approaches for enhancing, conserving or restoring fisheries (Bell et al. 2006,
Camp et al. 2013). Cultivation-based enhancements may provide various benefits, such as a useful support to fisheries stock, an increase in fishery performance and catch rate, and protection and renewal of depleted, threatened and endangered fish populations (Lorenzen 
et al. 2012, Camp et al. 2013). This enhancement may provide economic and social benefits, supporting the recreational and commercial fishery and offering incentives for active management and better governance of fisheries resources (Camp et al. 2013).

We examined the turbot, Psetta maxima (Linné, 1758), which is one of the most commercially important flatfishes in the Black Sea region (Zengin 2000). Turbots have generally been caught by bottom trawlers and bottom-set gillnets as target species and by purse seines as a by-catch in Turkish waters of the Black Sea. Between 1990 and 2010, total landings of turbot in the Black Sea ranged between 450 and 3000 t. In recent years, turbot landings have shown significant decreases, but it was reported that the catches increased gradually from $145 \mathrm{t}$ in the 2011 to $172 \mathrm{t}$ in $2012,195 \mathrm{t}$ in 2013 and $197 \mathrm{t}$ in 2014 (TUIK 2014). An increasing fishing effort was made by the Turkish fleet mainly in the fishing periods between 2010 and 2013. Trends in total catch were analogous to the increase in the number of vessels (STECF 2014). Fishing mortality (F) of turbots was $0.63,0.74,0.95$ and 1.26 in 2010, 2011, 2012 and 2013, respectively (STECF 2014). These F values of this species in Black Sea region reflect the high over-exploitation pressure on turbot stocks by the commercial fishery. According to the latest statistics, average TLs and landings are decreasing (STECF 2014). To preserve and maintain these valuable stocks, harvesting turbot smaller than $45 \mathrm{~cm}$, the minimum legal fishing size (Anonymous 2016), must be prevented. Turbot is generally preferred in this area and consequently priced at a high level $(20-25 € / \mathrm{kg}$ in the Trabzon Fish Market, pers. comm.).

In addition to overfishing and anthropogenic pressures, the marine ecosystem of Black Sea has been influenced by coastal development and changing environmental conditions (Lotze et al. 2006, Lejeusne et al. 2010). The coastal zone is a very important habitat for fish protection, feeding and shelter, with a reduced risk of predation (Krumme 2009). This finding is corroborated by the idea that these important ecosystems are also affected by environmental fluctuations in temperature, currents and climate (Cury et al. 2008). These physical parameters have dramatically changed the narrow continental shelves and caused the loss of local nursery habitats in the Black Sea. This situation negatively affects the turbot's early juvenile stages, since its nursery grounds are generally located near coastal benthic communities at up to 5-10 m depth (Gibson 1994, Giragosov and Khanaychenko 2012). After this stage, the juveniles migrate to deeper waters (10-20 m) for feeding, whereas the adults inhabit various depths, up to $110 \mathrm{~m}$ (Giragosov and Khanaychenko 2012). The spawning period of turbot in the Black Sea extends from April to June at water temperatures of $12^{\circ} \mathrm{C}$ to $18^{\circ} \mathrm{C}$, with a peak in May. Turbot first mature sexually at the age of 4 years (Genç et al. 2002).

In last two decades, enhancement programmes have been conducted by the Central Fisheries Research Institute (CFRI-Trabzon) in order to preserve the insufficient wild stock or increase the number of fish recruiting to the freshwater or marine fishing stock. The first attempt was carried out on a total of 28876 hatcheryreared turbot specimens that were tagged and released in the southeastern Black Sea between 1999 and 2002 (Zengin et al. 2005). Some of them were captured via bottom trawls, gill nets and purse seine and the capture rate was $2.2 \%$. It was reported that the examined species exhibited vertical migrations depending on age, size and season. This study differed from that carried out by Zengin et al. (2005) due to the different sampling area and period, the different environmental parameters and the different fishery effort exerted on the studied species in the period. CFRI also conducted a stock enhancement of Black Sea trout (Çakmak et al. 2008) and sturgeon in the middle of Black Sea region (Zengin et al. 2015).

The present study is the first to describe the catch ratio, residence time, movements, feeding and growth of hatchery-reared turbots released in the Black Sea. The aim was to improve our knowledge of the biological and ecological characteristics of the released turbots and to assess the possibility of these released specimens being used to enrich the local wild population.

\section{MATERIALS AND METHODS}

\section{Area}

The study area was the wide area of Trabzon, Turkey, which is located near the southeastern coast of the Black Sea (Fig. 1). The continental shelves are narrow and the bottom areas are usually rocky, but sandy bottoms are also found in the deep valleys. The fishery activity in the sampling area is carrying out mainly by purse seines and bottom-set gillnets. However, the commercial trawl fishery is now banned in this area throughout the year by the Turkish Fishery Regulation Circular due to the overfished status of the fishery resources (Anonymous 2016). The area is considered to be a suitable region for release because of the sandy, shallow, flat characteristics that provide suitable living conditions for the turbot. In this particular part of the Black Sea, the surface water temperature ranges between $7^{\circ} \mathrm{C}$ and $28^{\circ} \mathrm{C}$ throughout the year; the lowest temperatures are observed in February and March and the highest ones in July and August. Below a depth of $50 \mathrm{~m}$, the temperature is almost stable at $5^{\circ} \mathrm{C}$ throughout the year.

\section{Tagging and releasing the juvenile fish}

Turbots were hatchery-produced from wild parental stocks at the Turbot Hatchery Unit, Fisheries Research Institute, Trabzon (CFRI) in May 2008. Turbot eggs and larvae for hatchery operation were provided by artificial fertilization of eggs from newly caught wild brood stock during the spawning season from April to May. Eggs generally hatch after 115 hours at a water temperature of $15^{\circ} \mathrm{C}$ and the larvae transform from the larval to the juvenile stage in about 70 days. At the end of this period, the larvae grow, adopt the adult form of turbot and enter the juvenile stage. Artificial diets of enriched rotifer and Artemia were 


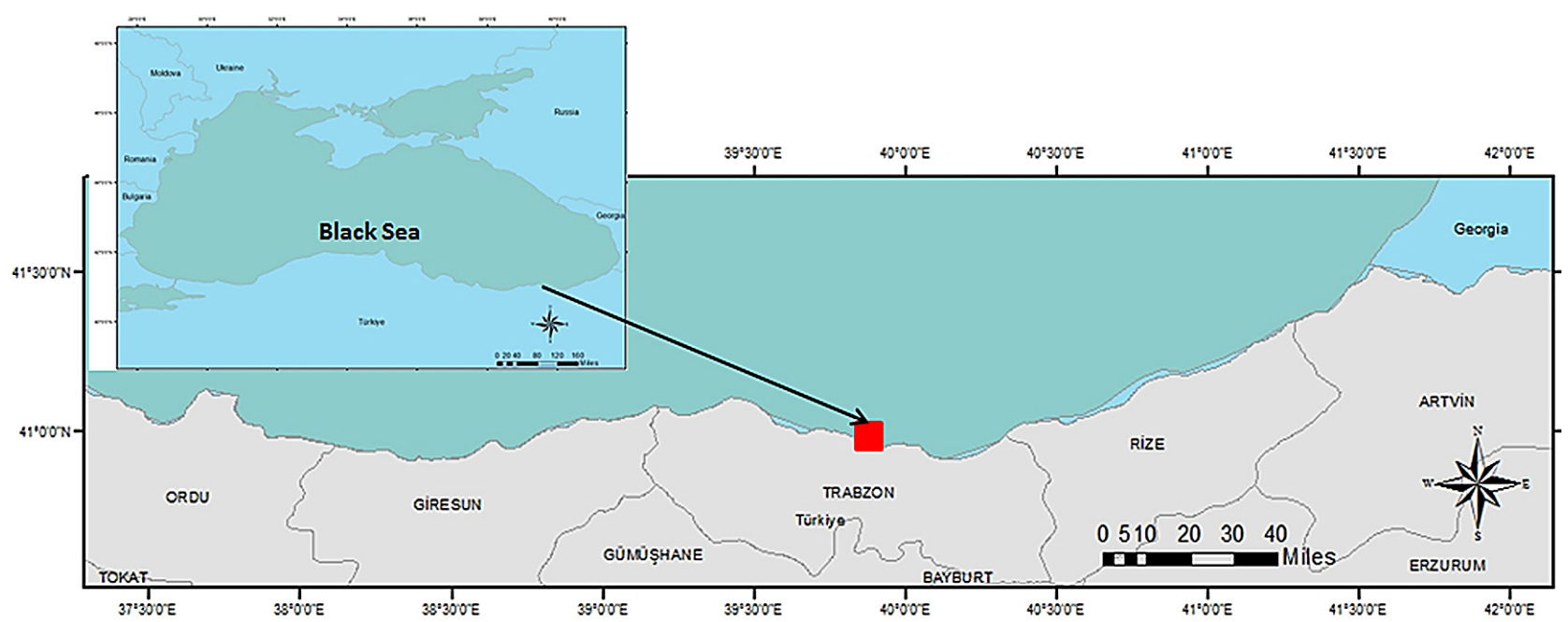

Fig. 1. - Area of release and capture of tagged turbots, P. maxima, during the study period.

used for larval feeding (Üstündağ et al. 2002). Juveniles were grown for approximately 8 months in fibre tanks with a water temperature of $21^{\circ} \mathrm{C}$ until release. Crumbled pellets of 0.7 to $1 \mathrm{~mm}$ diameter were used for juvenile rearing. As the fish grew, crumbled pellets were gradually replaced by a pelletized diet. The feeding rate of juvenile turbot started at $4 \%$ to $5 \%$ of body weight four to five times a day at about 20-50 $\mathrm{mm}$ total length (TL) and was gradually decreased to $2 \%$ to $3 \%$ of body weight three to four times a day at about $100 \mathrm{~mm}$ TL (Üstündağ 2003)

The mean TL and weight of 800 turbot individuals, individually measured prior to release, were between 9 and $17 \mathrm{~cm}$ (mean length and standard deviation $12.91 \pm 1.25 \mathrm{~cm})$ and 11 and $88.2 \mathrm{~g}(35.41 \mathrm{~g} \pm 12.38 \mathrm{~g})$, respectively. To separate the hatchery-released fishes from the wild ones, juvenile turbots were individually marked with plastic serial numbers using external Tbar anchor tags. Turbots that were almost eight months old were tagged under the dorsal fin, into the muscle tissue. During the tagging, sick and disabled individuals were discarded. Marked fishes were treated with oxytetracycline at $100 \mathrm{ppm}$ for 30 minutes against potential infections (Kim et al. 2014). All turbots were tagged at least two weeks before release, and then kept and closely observed in the fibre tank until the time of release.

The fishes were transported from the hatchery unit to the area of release via a ship. The duration of the transfer was almost two hours; a continuous oxygen supply was given during this period. The fishes were released into the sea by bucket to approximately 20-30 $m$ depth of the sea between 15 and 18 January 2009 in the Trabzon area. A total of 9933 turbots were individually marked and then released to the sea.

\section{Captured fishes}

Tagged turbots were bought from the local market and also caught during the trawl surveys by R/V Sürat Araștırma-1 in the southeastern Black Sea. Tagged fishes were caught by fishermen via purse seine, bot- tom-set gillnet and hooks. Fishermen were supported with a gift of new auxiliary equipment for their activity, such as a raincoat, in exchange for returning tags and reporting catch data, TL (including minimum legal size) and condition of the fish. Trawl surveys were carried out by the bottom trawler of the R/V Sürat Arasstırma-1 from Ordu to the borders of Georgia. The bottom trawler had a cod-end mesh size of $14 \times 12 \mathrm{~mm}$, a vertical height of $12 \mathrm{~m}$ and a horizontal opening of $22.5 \mathrm{~m}$. The duration of the haul was 30 minutes. A total of 46 hauls (12 in spring, 12 in summer, 12 in autumn and 10 in winter) were carried out during the study. A total of 33 wild and 89 tagged turbot were caught. The date, area, time, depth, fishing gear, duration of the survey, tag number of the captured fish and length and weight of the samples at the moment of capture were recorded. The number of wild turbots in the catch of trawl operations was also recorded and measured on board the research vessel.

A total of 270 tagged individuals were caught (160 by bottom gillnet; 89 by trawl survey; 20 by purse seine; 1 by hook). Catch rate was calculated according to the formula:

\section{Capture rate $=($ number of tagged fish caught/number} of fish released) $* 100$.

The biological characteristics (length, weight, growth, diet) of 218 individuals were measured. The TL of the specimens was measured to the nearest millimetre, and the body weight to the nearest gram, and then they were separated by sex.

\section{Sex ratio}

Gonads were extracted and structural differences of the genitals were examined with the naked eye for sexing. The fishes whose gonads had a granular structure were identified as females and the other fishes were evaluated as male samples. The female:male ratio was calculated for all the individuals (Holden and Raitt 1974). 


\section{Growth}

Data from the tagged fishes caught from the commercial fishery and trawl surveys were also used in the growth analysis. The growth in length in the individuals released and caught was calculated by year and tested with a t-test. Annual growth ratio (AGR) of the released specimens was calculated as follows:

$$
\mathrm{AGR}=\frac{\mathrm{L}_{\text {final }}-\mathrm{L}_{\text {initial }}}{\text { time interval }} 365
$$

where $\mathrm{L}_{\text {final }}$ is length at the moment of capture and $\mathrm{L}_{\text {initial }}$ is length at the moment of release. Time interval is the number of days at liberty experienced by captured fish.

The length-weight relationship of captured fishes was calculated according to $\mathrm{W}=\mathrm{aL}^{\mathrm{b}}$ and Fulton's condition factor $(\mathrm{K})$ of the individuals released and recaptured by the equation

$$
\mathrm{K}=\frac{\mathrm{W}}{\mathrm{L}^{3}} 100
$$

where $\mathrm{W}$ is the weight of captured fish, $\mathrm{L}$ is the TL of fish, and parameter ' $a$ ' is a scaling coefficient for the weight at length of the fish species and parameter ' $b$ ' is a shape parameter for the body form of the fish species. The Student t-test was used to test whether the slopes (b) were significantly different from 3 , indicating the growth type: isometric $(b=3)$, positive allometric $(b>3)$ or negative allometric $(b<3)$.

The birth date of hatchery turbots was known as May 2008. The age was calculated as the time between the date of birth and the date of capture. The von Bertalanffy growth parameters were calculated according to the equation $\mathrm{L}_{\mathrm{t}}=\mathrm{L}_{\infty}\left[1-\mathrm{e}^{-\mathrm{k}}\left(\mathrm{t}-\mathrm{t}_{0}\right)\right]$, where $\mathrm{L}_{\mathrm{t}}$ is length of fish $(\mathrm{cm})$ at age $\mathrm{t}, \mathrm{L}_{\infty}$ is the asymptotic fish length $(\mathrm{cm}), \mathrm{t}$ is the fish age (year), $t_{0}$ is the hypothetical time at which the length of fish is zero and $\mathrm{k}$ is the growth coefficient $\left(\right.$ year $^{-1}$ ) (according to Sparre and Venema 1992).

The growth performance index $(\Phi)$ was estimated using the equation, where $\mathrm{L}_{\infty}$ and $\mathrm{K}$ are parameters of the von Bertalanffy growth equation (Pauly and Munro $1984)$. The growth performance index $(\Phi)$ reflects the growth rate of the fish of unit length and is connected with the integration of growth, the metabolism and the food consumption of $\Phi=\ln (\mathrm{k})+2 \ln \left(\mathrm{L}_{\infty}\right)$ an organism (Pauly and Munro 1984).

\section{Migration}

Horizontal and vertical movements of tagged turbots, which reach the bottom, were estimated in the study area. The catch area, date and depth were recorded from fishermen and from trawl surveys $(n=270)$. The distance between the area of release and the area of capture was measured for every individual as km (Støttrup et al. 2002). According to the capture distance, the fishes were referred to as "resident" $(<10 \mathrm{~km})$ or "migratory" (>10 km) individuals.

\section{Stomach contents}

The stomachs of each fish were placed in the plas- tic bags and frozen $\left(-20^{\circ} \mathrm{C}\right)$ for further analysis. For 52 tagged fishes, the tag was removed by fisherman and only the date and area of capture were recorded $(n=218)$.

The vacuity index $V=\left(\mathrm{N}_{\mathrm{e}} / \mathrm{N}_{\mathrm{s}}\right)$ was calculated, where $\mathrm{N}_{\mathrm{e}}$ is the number of empty stomachs and $\mathrm{N}_{\mathrm{s}}$ is the total number of stomachs examined. The percentage of empty stomachs and the repletion index (RI=wet weight of gut content*100/wet body weight) were used to evaluate the feeding activity of fish (Cortés et al. 1996).

Two indices, the frequency of occurrence $\left(\mathrm{O}_{\mathrm{i}} \%\right)$ and the relative abundance $\left(\mathrm{N}_{\mathrm{i}} \%\right)$ for every prey type and the total wet weight of gut content were used to describe the diet of the fish examined. In addition, the index of relative importance $\left(\operatorname{IRI}_{\mathrm{i}}\right.$ ) was also calculated (Hyslop 1980, Cortés et al. 1996). All the indices were computed according to the formulas below:

$$
\begin{gathered}
\mathrm{O}_{\mathrm{i}} \%=\left(\mathrm{FO}_{\mathrm{i}} / \mathrm{N}_{\mathrm{s}}\right) 100 \\
\mathrm{~N}_{\mathrm{i}} \%=\left(\mathrm{N}_{\mathrm{i}} / \mathrm{N}_{\mathrm{p}}\right) 100 \\
\text { IRI }_{\mathrm{i}}=\left(\mathrm{N}_{\mathrm{i}} \%+\mathrm{N}_{\mathrm{p}} \%\right) \mathrm{O}_{\mathrm{i}} \%
\end{gathered}
$$

where $\mathrm{O}_{\mathrm{i}} \%$ is the percent frequency of occurrence of prey $\mathrm{i}, \mathrm{FO}_{\mathrm{i}}$ is the frequency of occurrence of prey $\mathrm{i}, \mathrm{N}_{\mathrm{s}}$ is the total number of stomachs examined, $\mathrm{N}_{\mathrm{i}} \%$ is the percent by number of prey $\mathrm{i}, \mathrm{N}_{\mathrm{i}}$ is the total number of prey $I$ and $N_{p}$ is the total number of prey.

\section{Statistical analysis}

Differences in samples were first based on the sample mean and standard error. A chi-square test was used to analyse differences in the sex ratio. All data sets to be compared were tested for normality prior to further statistical analysis. A Mann-Whitney Test was used to elucidate the correlation between TL, weight and condition factor and the number of recaptured fishes per gear. The parameter (b) of L-WR was compared for significant difference between sexes by analysis of covariance (ANCOVA) (Zar 1996).

Differences in samples were based on the mean value and standard error of the samples. All data sets were tested for normality and equal variances prior to further statistical analysis. Statistical analysis was performed using a Kruskall-Wallis test, a t-test and a chi-square test (Zar 1996).

All statistical tests were carried out with PAST3.0, downloaded from http://folk.uio.no/ohammer/past/, except for the area estimation, which was done using the ArcGIS 10.1 software.

\section{RESULTS}

\section{Catch}

A total of 9933 turbots were tagged and 270 returned. Many individuals were captured only in the period 2009-2012. The overall catch ratio was $2.7 \%$ for the entire study period. The corresponding values for capture ratio of fishes aged $0^{+}$to $5^{+}$years were $0.3 \%$, $0.99 \%, 0.5 \%, 0.86 \%, 0.02 \%$ and $0.05 \%$, respectively. The numbers of tagged turbot recaptured by gill nets, scientific trawlers, purse seine and hook were 59.5\%, 


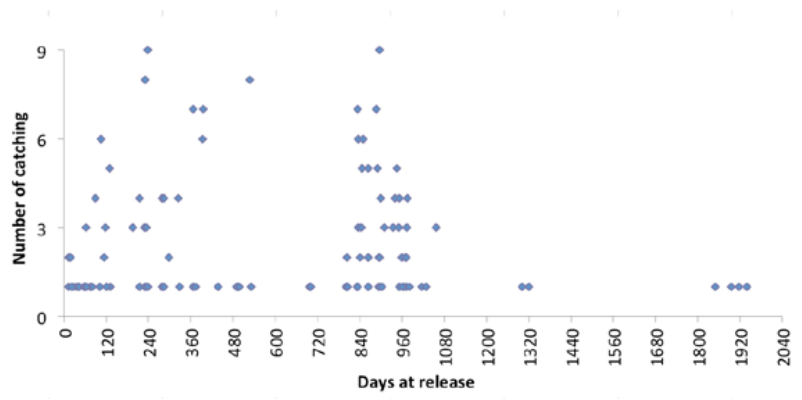

Fig. 2. - Number of captures of tagged turbots, $P$. maxima $(\mathrm{n}=270)$, in the sampling period.

$33 \%$ and $7 \%$ and $0.5 \%$, respectively. The capture rate of turbots by bottom-set gillnet was not significantly higher than the capture rate by the trawlers (t-test $\mathrm{p}>0.05$ ), but showed a significant difference from that of the other fishing gears (t-test, $\mathrm{p}<0.05$ ).

The average time between release and capture for tagged turbots was 571 days $( \pm 22.25 \mathrm{SE}, \mathrm{n}=218)$, ranging from 3 to 1987 days. The percentage of captured fishes was $8.14 \%$ in 100 days $(n=22), 37.03 \%$ in 400 days $(n=100), 6.66 \%$ in 700 days $(n=18), 45.92 \%$ in 1100 days $(n=124), 0.74 \%$ in 1250 days $(n=2)$, and $1.48 \%$ in 1950 days $(n=4)$. Therefore, $99.97 \%$ of the captures were made between 0.9 and 5.3 years (Fig. 2).

\section{Wild and tagged turbots}

A total of 33 wild and 89 tagged turbots were caught from trawl surveys between 2009 and 2014. The proportion of wild to released fishes during 46 trawler surveys was 1:2.69. Forty-two percent of tagged fishes and seventy percent of wild turbots were caught at depths of 20-40 m.

\section{Sex ratio}

The sex ratio of 218 captured tagged turbots during the sampling period (2009-2014) was 1:0.92 in favour of females. There were no significant difference from the expected ratio of $1: 1\left(\chi^{2}=0.05, p>0.05\right)$. In the spawning season from April to June 2012, 21 mature turbots were caught.

The tagged individuals reached sexual maturity at the age of $4^{+}$years, when they were usually found at the depth range 15-50 $\mathrm{m}$ in April and May 2012 for spawning. According to the results of this study, only a few individuals of both sexes showed gonad maturation during April-May.

\section{Growth}

The mean body length of captured turbots was 31.17 $\mathrm{cm}(\min =12.3 \mathrm{~cm}, \max =68 \mathrm{~cm}, \mathrm{n}=218)$. The mean body length varied between the ages (Fig. 3). The mean body weight of the captured turbots was $878.08 \mathrm{~g}$ ( $\mathrm{min}=22.57$ $\mathrm{g}, \max =5795 \mathrm{~g}, \mathrm{n}=218$ ). Of captured turbots, $93.1 \%$ were $\leq 2000 \mathrm{~g}, 4.1 \%$ were $\leq 4000 \mathrm{~g}$ and $2.8 \%$ were $>4000$ $\mathrm{g}$ (Fig. 4). The mean increases in length and weight after the release were significantly different between ages (Kruskal-Wallis test, $\mathrm{p}<0.005$ ). The size and weight of

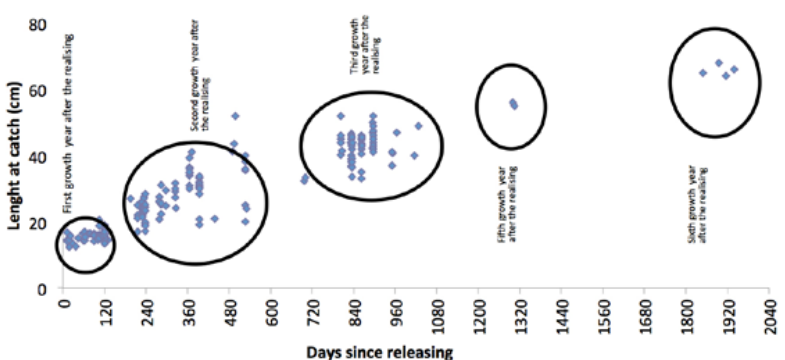

Fig. 3. - Length at capture of tagged turbots, $P$. maxima $(\mathrm{n}=218)$, in the sampling period. Black circle, fishes caught per year, Point, date and length at catch.

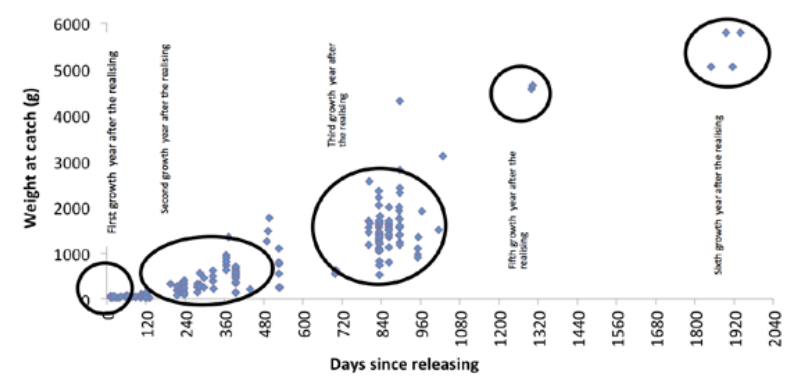

Fig. 4. - Weight at capture of tagged turbots, $P$. maxima $(\mathrm{n}=218)$, in the sampling period. Black circle, fishes caught per year, Point, date and length at catch.

the biggest captured turbot were $68 \mathrm{~cm} \mathrm{TL}$ and $5795 \mathrm{~g}$ $\mathrm{W}$ at an age of $5^{+}, 64$ months (1987 day) after release (Figs 3, 4). The legal minimum landing size (45 cm TL) was reached at end of the $3^{+}$age. Only $15 \%$ of captured turbots reached the legal size.

The mean annual growth rates of captured turbots belonging to the ages between $0^{+}$and $5^{+}$years were $15.10 \pm 1.63,16.15 \pm 0.62, \quad 12.82 \pm 0.23,12.82 \pm 0.47$, $11.93 \pm 0.15$ and $10.15 \pm 0.18 \mathrm{~cm} /$ year, respectively (Fig. 5). The highest growth rate was found in 2010 $(16.15 \pm 0.62 \mathrm{~cm})$. The lowest growth rate was found in $2014(10.15 \pm 0.18 \mathrm{~cm})$. There was a significant effect in annual growth rates (Kruskal-Wallis test, $\mathrm{p}<0.005$ ). There was no significant relationship between the location of capture and the sex of caught fishes $(p>0.005)$.

\section{The length-weight relationship}

The length-weight relationship of all the tagged turbots was and $r=0.99$. The b value (3.21) suggested that the fish followed a positive allometric growth pattern $(b>3)$. No significant differences were found in the

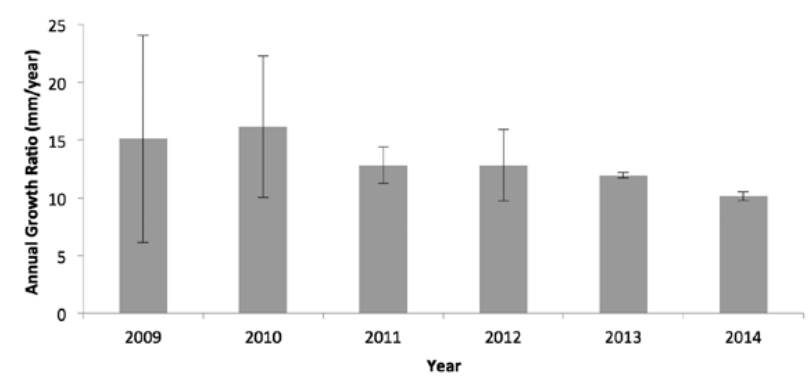

Fig. 5. - Annual growth ratio (AGR) by year for captured tagged turbot, $P$. maxima $(\mathrm{n}=218)$. Fig. 6. - von Bertalanffy growth curve for captured tagged turbots, $P$. maxima $(\mathrm{n}=218)$. 


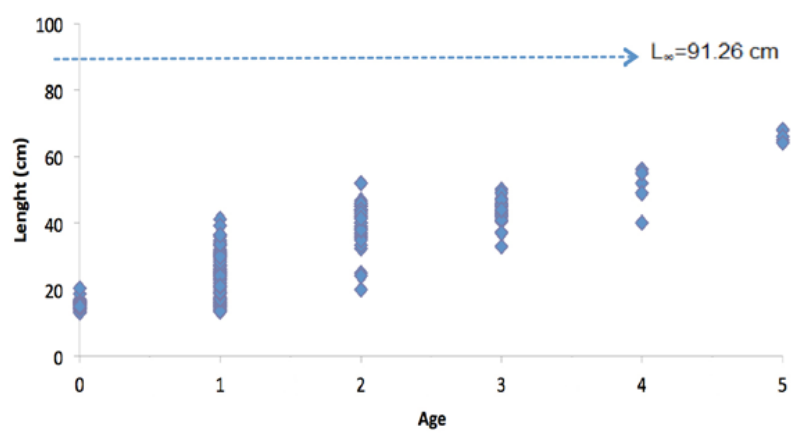

Fig. 6. - von Bertalanffy growth curve for captured tagged turbots, $P$. $\operatorname{maxima}(\mathrm{n}=218)$. b values of length-weight relationships of both sexes within seasons (ANCOVA, $\mathrm{p}>0.05$ ). This means that the female and male individuals had the same body shapes in the same seasons.

The von Bertalanffy growth parameters of all the tagged fishes were $\mathrm{L}_{\infty}=91.26 \mathrm{~cm}, \mathrm{k}=0.16$ year $^{-1}$ and $\mathrm{t}_{0}=-1.19$ year (Fig. 6). The growth performance index $(\Phi)$ was 7.19 for all tagged turbot caught.

\section{Condition factor}

Before release, initial condition factor $(\mathrm{K})$ ranged between 1.15 and 2.09 (mean 1.57士0.005). Condition
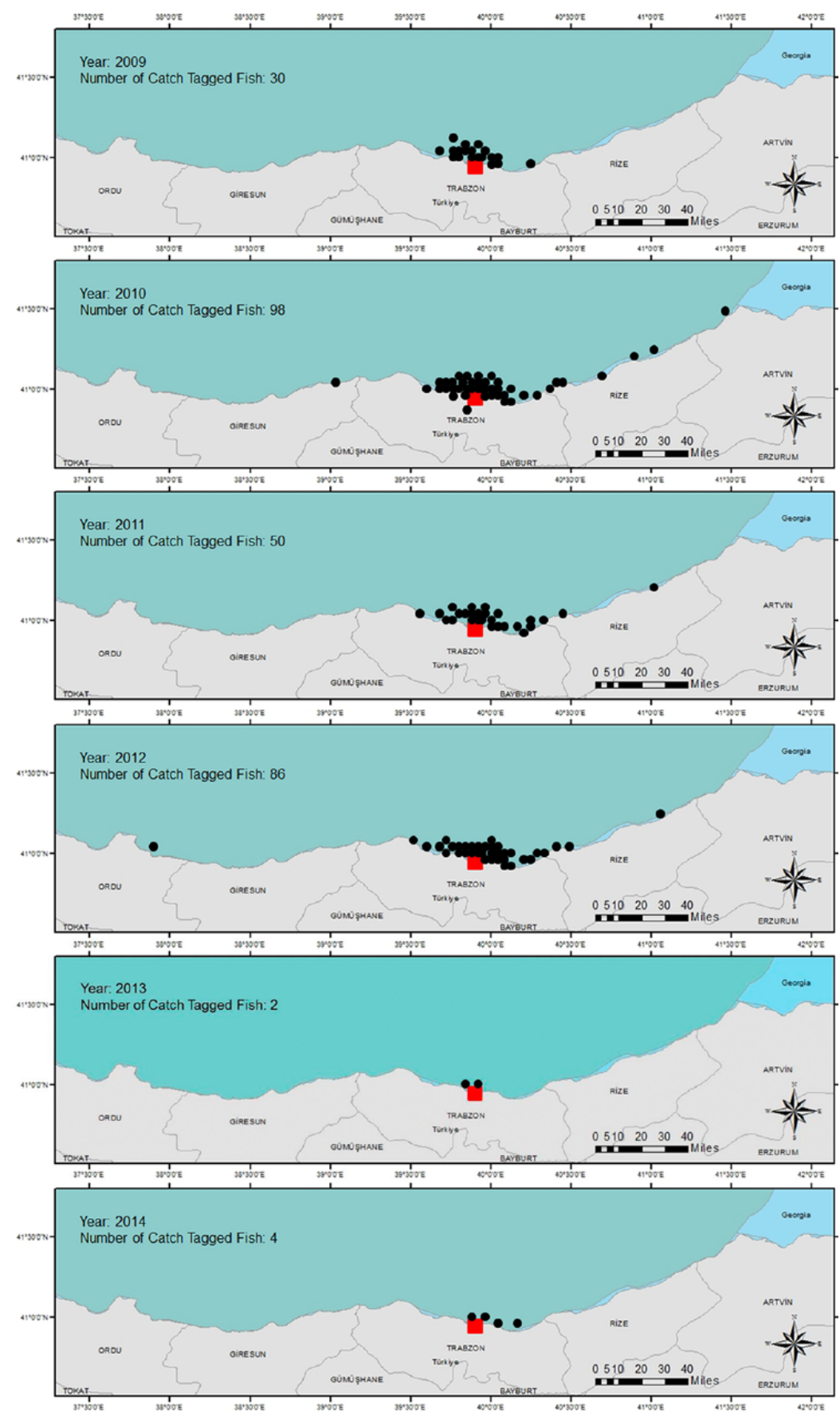

Fig. 7. - Horizontal and vertical range of movement of tagged turbots after release by year. Red square, area of release (Havaalanı area); black point, catch point of fish. Number of fishes caught between 2009 and 2014: 270. 
Table 1. - Values for percentage by number (N\%), weight (W\%), occurrence (O and O\%), and index of relative importance (IRI and IRI\%) for prey items observed in stomachs $(\mathrm{n}=218)$ of captured turbots (Psetta maxima).

\begin{tabular}{|c|c|c|c|c|c|c|c|c|}
\hline & Prey groups & $\mathrm{N}$ & $\mathrm{N} \%$ & $\mathrm{~W} \%$ & $\mathrm{O}$ & $\mathrm{O} \%$ & IRI & IRI\% \\
\hline Fishes & $\begin{array}{l}\text { Merlangius merlangus euxinus } \\
\text { Engraulis encrasicolus } \\
\text { Mullus barbatus ponticus } \\
\text { Sprattus sprattus } \\
\text { Gobius niger } \\
\text { Spicara smaris } \\
\text { Trachurus mediterraneus }\end{array}$ & $\begin{array}{c}55 \\
22 \\
15 \\
5 \\
4 \\
4 \\
3 \\
\mathbf{1 0 8}\end{array}$ & $\begin{array}{c}48.67 \\
19.47 \\
13.27 \\
4.42 \\
3.54 \\
3.54 \\
2.65 \\
\mathbf{9 5 . 5 8}\end{array}$ & $\begin{array}{c}66.88 \\
10.58 \\
11.57 \\
2.07 \\
2.98 \\
2.72 \\
1.93 \\
\mathbf{9 8 . 7 3}\end{array}$ & $\begin{array}{c}41 \\
13 \\
10 \\
4 \\
3 \\
3 \\
2 \\
76\end{array}$ & $\begin{array}{c}50.62 \\
16.05 \\
12.35 \\
4.94 \\
3.70 \\
3.70 \\
2.47 \\
\mathbf{9 3 . 8 3}\end{array}$ & $\begin{array}{c}5848.78 \\
482.31 \\
306.69 \\
32.05 \\
24.14 \\
23.19 \\
11.33 \\
\mathbf{6 7 2 8 . 4 9}\end{array}$ & $\begin{array}{c}86.79 \\
7.16 \\
4.55 \\
0.48 \\
0.36 \\
0.34 \\
0.17 \\
\mathbf{9 9 . 8 5}\end{array}$ \\
\hline Crustacea & $\begin{array}{l}\text { Liocarcinus depurator } \\
\text { Crangon crangon }\end{array}$ & $\begin{array}{l}2 \\
1 \\
3\end{array}$ & $\begin{array}{l}1.77 \\
0.88 \\
\mathbf{2 . 6 5}\end{array}$ & $\begin{array}{l}0.76 \\
0.43 \\
\mathbf{1 . 1 9}\end{array}$ & $\begin{array}{l}2 \\
1 \\
3\end{array}$ & $\begin{array}{l}2.47 \\
1.23 \\
\mathbf{3 . 7 0}\end{array}$ & $\begin{array}{l}6.26 \\
1.62 \\
7.87\end{array}$ & $\begin{array}{l}0.09 \\
0.02 \\
\mathbf{0 . 1 2}\end{array}$ \\
\hline Mollusca & $\begin{array}{l}\text { Gibbula divaricata } \\
\text { Cyclopea neritea }\end{array}$ & $\begin{array}{l}1 \\
1 \\
2\end{array}$ & $\begin{array}{l}0.88 \\
0.88 \\
\mathbf{1 . 7 7}\end{array}$ & $\begin{array}{l}0.02 \\
0.06 \\
\mathbf{0 . 0 8}\end{array}$ & $\begin{array}{l}1 \\
1 \\
2\end{array}$ & $\begin{array}{l}1.23 \\
1.23 \\
\mathbf{2 . 4 7}\end{array}$ & $\begin{array}{l}1.12 \\
1.17 \\
\mathbf{2 . 2 9}\end{array}$ & $\begin{array}{l}0.02 \\
0.02 \\
\mathbf{0 . 0 3}\end{array}$ \\
\hline & Total & 113 & 100 & 100 & 81 & 100 & 6738.66 & 100 \\
\hline
\end{tabular}

factor values of captured turbots were generally lower than those of hatchery-released specimens, ranging between 0.74 and 2.75. Mean values of condition factors $( \pm \mathrm{SE}$, range $)$ of $0^{+}$- to $5^{+}$-year-old turbots were $1.36( \pm 0.026,0.99-1.70), 1.72( \pm 0.028,0.74-2.75)$, $1.84( \pm 0.062,1.25-2.75), 1.88( \pm 0.036,1.59-2.61)$, $2.68( \pm 0.117,2.34-2.75)$ and $1.90( \pm 0.041,1.83-2.01)$, respectively. These values indicate that there was an increase of $\mathrm{K}$ with age, except in the fishes belonging to the $5^{+}$age, although it was not statistically significant (ANOVA, $\mathrm{F}=1.036, \mathrm{p}=0.366$ ). In first year after release, turbot lost an average of $16 \%$ of their initial condition factor.

\section{Migration}

The number of turbots captured close to the area of release $(<10 \mathrm{~km}$, east and west of the release area) was significantly higher than that in the east and the west directions $(\mathrm{p}<0.05)$. Tagged fishes usually moved to the east, indicating a significant pattern of migration.

After release, the turbots showed both vertical and horizontal distribution (Fig. 7). They were caught in all seasons, particularly in the eastern Black Sea. In the first few months $\left(0^{+}\right.$age, until May 2009), the turbots showed a relative expansion and depth preference for between 20 and $40 \mathrm{~m}$. During the whole study period in the study area, individuals larger than $30 \mathrm{~cm}$ were mainly caught in spring in the depth range $30-90 \mathrm{~m}$, indicating a larger geographical distribution from the release area to the borders of Georgia and the western region. Individuals aged $3^{+}$years and more showed a vertical migration for spawning behaviour in spring. In 2011 and 2012 a total of 76 individuals were caught below $45 \mathrm{~m}$ depth.

Captured turbots predominantly showed movements from the west to the east from the area of release during the study period (2009-2014). In the first and the second month after the release, an individual moved westwards for up to $15 \mathrm{~km}$ but other specimens moved eastwards for up to $31 \mathrm{~km}$ (Fig. 7). Turbots were captured close to their area of release in $2009(n=30)$ and the average distance $(\mathrm{km})$ from release to capture location was $9.6 \mathrm{~km}( \pm 5.1 \mathrm{SE}$, max. distance $=50 \mathrm{~km})$. According to the fishes captured in 2009 , turbots can be considered as "resident" $(86.2 \%<10 \mathrm{~km})$. In 2010 and 2011 years, the distance covered by some fishes was greater, since many captures were made at a distance of more than $10 \mathrm{~km}$. The median distance was only 20 and $28 \mathrm{~km}$ in the second the third year after release, respectively. In these years, a total of $62.2 \%$ of all captured turbots were caught within $10 \mathrm{~km}, 26.3 \%$ within 100 $\mathrm{km}$ and $11.5 \%$ within $150 \mathrm{~km}$. In other words, $37.8 \%$ of the captured fishes were "migratory" and the rest were "resident". In 2012, 70\% of the captured fishes were captured around the release area $(<10 \mathrm{~km})$, while the rest $(>10 \mathrm{~km})$ moved for an average distance of 16 $\mathrm{km}( \pm 5.3 \mathrm{SE}, \max$. distance $=150 \mathrm{~km}$, to west $)$. Therefore, for 2012 many of the individuals of the species can be considered "resident" $(65.2 \%<10 \mathrm{~km})$. However, some individuals $(35.2 \%)$ travelled more than 10 km. In 2013 and 2014, all fish were "resident" because they were found within shorter distances $(<10 \mathrm{~km})$. A total of $54.8 \%$ of all the captured turbots were caught within $10 \mathrm{~km}, 35.5 \%$ within $100 \mathrm{~km}$, and $9.7 \%$ within $150 \mathrm{~km}$ (Fig. 7).

\section{Feeding}

The feeding habits of 218 specimens of tagged captured individuals were studied. In the entire study period 76 empty stomachs $(34.8 \%$ of the total examined stomachs) were found. In the first winter and spring after release, empty stomachs were found in winter $(47.05 \%)$ and spring $(54.54 \%)$, but there was no significant seasonal difference $(\mathrm{p}>0.05)$. However, in the first summer and autumn, only one individual was caught. The majority of totally empty stomachs were found in summer $(61.11 \%)$ and winter $(60.52 \%)$ but no significant seasonal difference was found $(\mathrm{p}>0.05)$. The stomachs were fuller in autumn (16.21\%) and spring $(23.36 \%)(\mathrm{p}>0.05)$ and the differences between the high vacuity index seasons (spring and autumn) and the low vacuity index seasons (summer and winter) were significant $(\mathrm{p}<0.05)$.

In general, three prey groups showed the highest abundance, occurrence and relative importance in the turbots' stomachs: teleost fishes, crustaceans and mollusks. The diet of captured individuals consisted of 11 prey categories (Table 1). The mean stomach weight 
content was $40.71 \pm 26.44 \mathrm{~g}$. The stomachs of three individuals caught on the third day after their release were empty. Engraulis encrasicolus and Cyclopea neritea were in the stomach of a specimen caught seven days after release.

\section{DISCUSSION}

\section{Effects of tagging}

Some of the T-bar anchor tags were covered by mussels. Some cases of injury were also visible on the marked point of the tissue surface to the naked eye (Fig. 8). Many studies have been carried out on tagging effects in different fishes (McFarlane et al. 1990, Thorstad et al. 2013). Within the present study, the use of T-bar anchor tags was found to be very advantageous, since they offered an increased return rate of turbots by fisherman. However, one disadvantage was that they were covered by mussels and this might affect the growth, health and survival of tagged fishes (Thorsteinsson et al. 2002).

\section{Capture}

The capture ratio for released turbots seemed to be similar (up to $2.7 \%$ ) to that of other studies. The number of tag returns from the release studies was mainly attributed to the temporal overfishing conditions. Zengin et al. (2005) corroborated the conclusion that the adaptation of $P$. maxima to the environmental conditions could be considered as one of the main conditions for the stock's survival, and reported that its catch rate ranged between $0.5 \%$ and $7.5 \%$ in the same area. Støttrup et al. (2002) also reported that the total capture ratio for the released turbots ranged from $1 \%$ to $11 \%$ between 1991 and 1998 in Danish waters. Aneer and Westin (1990) obtained $12 \%$ to $27 \%$ recaptures of turbot, and Delbare and De Clerck (2000) reported the recapture ratio to be $16 \%$ in North Baltic Sea.

Turbots also migrated to shallow waters $(<45 \mathrm{~m})$ for spawning. As shown in the present study, the capture rate increased when the fishing mortality simultaneously increased, particularly during spawning time (April-May).

Between 8 and 9 months could be considered the most suitable age and length for turbot release, because they have an increased ability of swimming and finding shelter, whereas higher losses in hatchery-reared fish may be associated with predation (Turek et al. 2012). The efficiency of turbot restocking programmes is often difficult to evaluate as information on natural stock abundance is rarely or only partially available. Most of these programmes were conducted with juveniles $\left(0^{+}\right.$or $1^{+}$year old $)$, which were released in shallow coastline habitats. Released turbot generally exhibit a relatively high mortality rate, similar to that of wild turbot (Støttrup et al. 2002). Hatchery-reared fishes for release into the field for stock enhancement must adapt to the conditions in their new environment, feed successfully and avoid predation if they are to survive (Howell 1994). Predation is the main cause of mortal-

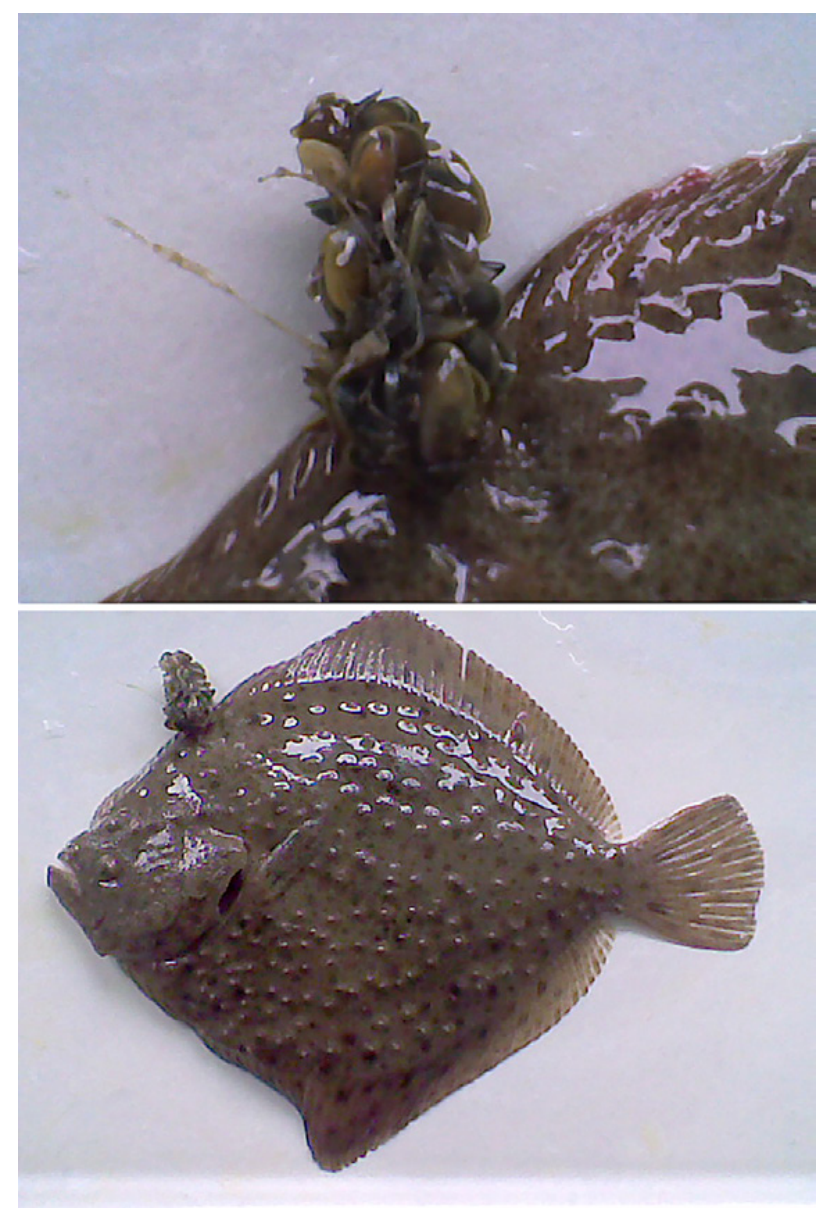

Fig. 8. - T-bar anchor tags covered with mussels (April 30, 2010 at Havaalanı region; TL, $36.5 \mathrm{~cm}$; weight, $824.6 \mathrm{~g}$; age, $1^{+}$, photo by Orhan Ak).

ity among released hatchery fish and the difference in mortality rates between hatchery-reared and wild fish is particularly important considering the size/age at which the fish are usually released (Howell 1994). The survival of cultured fishes that are released into coastal ecosystems is partly mediated by the size of fishes at the time of release into the wild (Leber et al. 2005). Size at release is also closely associated with the cost of culturing juveniles in the hatchery (Leber et al. 2005, Munro and Bell 1997). The best size at release for economic efficiency is sometimes different from the ecologically optimal size at release (Yamashita and Yamada 1999). For example, the average size at release in the flounder stock enhancement programme in Japan has increased from almost $50 \mathrm{~mm}$ TL in the early $1980 \mathrm{~s}$ to $80 \mathrm{~mm}$ in recent years.

\section{Sex ratio}

Despite the increased fishing pressure on demersal and pelagic fishes (STECF 2014) and the current loss of local nursery habitats in this area, tagged turbots were able to protect themselves and reached sexual maturity at the age of $4^{+}$years in the southeastern Black Sea region. The species is very sensitive to high fishing pressure due to its long life span and relatively late reproduction onset (Panayotova et al. 2012). In this 
study, although only a few tagged turbot individuals (21) reached sexual maturity, this fact suggests that even some hatchery fishes reached sexual maturity and thus had the opportunity to rebuild the natural age structure and provide the next generation of broodstock. The same concern was raised by Ireland et al. (2002) in their study on the release of the white sturgeon Acipenser trasmontanus in the Kootenai River (USA). We suggest that the tagged fishes adapted to the wild environmental.

\section{Growth}

Tagged turbot reached the legal size $(45 \mathrm{~cm}$, TL) in the third year of their growth. In this study, the latest data on captured fish showed that maximum length, weight and age of tagged turbot were $68 \mathrm{~cm}, 5795 \mathrm{~g}$ and $5^{+}$years, respectively. Zengin et al. (2005) reported that the maximum length and age of the tagged turbots captured was $54.2 \mathrm{~cm}$ and $4^{+}$, while in the present study the same species belonging to the same age $\left(4^{+}\right)$had a mean length of $45-55 \mathrm{~cm}$.

In this study, the annual growth rate ranged between 10 and $16 \mathrm{~cm}$ for all specimens. Zengin et al. (2005) reported an annual growth rate of 8-17 cm in the same area, but Støttrup et al. (2002) found an annual growth rate of $5-11 \mathrm{~cm}$ in Danish waters for the same species and years. Some authors reported that growth is related to both water temperature and food availability in some flatfishes, such as turbot (Psetta maxima) (Støttrup et al. 2002, Zengin et al. 2005), Japanese flounder (Paralichthys olivaceus) (Lv et al. 2011) and winter flounder (Pseudopleuronectes americanus) (Sogard and Able 1992).

While tagged turbots reached the legal catch length in the third year of their lifespan, specimens of the wild population reached this size at the same age too (Suzuki et al. 2002). The high growth rates of released turbot individuals in the first two years were similar to those of the wild population, as estimated by Zengin et al. (2005). This situation indicates that tagged turbots adapted their biological needs to the marine environmental parameters. If these tagged individuals could not feed well in sea, they would be likely to reach reproductive age later (Zengin et al. 2005).

The strong positive allometric growth of $P$. maxima has also been found in other studies in Black Sea. The $\mathrm{b}$ value of the length-weight relationship in the present study was within the range 3.10-3.43 reported in the Black Sea by Ivanov and Beverton (1985); Samsun (1995), Erdem (1997) and Zengin et al. (2005).

In this study, the estimated growth coefficient $(\mathrm{k})$ and asymptotic sizes $\left(\mathrm{L}_{\infty}\right)$ did not differ from other values obtained in other examined areas. Therefore, differences in asymptotic sizes $\left(\mathrm{L}_{\infty}\right)$ between the present and previous studies might show differences in growth rates (Arneri et al. 2001). Although turbot is genetically homogeneous throughout its geographical range (Blanquer et al. 1992), its growth rate varies with a high geographical variability (Arneri et al. 2001). In the southeastern Black Sea, the growth rate is slightly higher than in the northwestern Black Sea (Ivanov and Beverton 1985, Genç et al. 2002) and the North Sea
(Mengi 1971, Jones 1976). In the Black Sea both sexes of turbot grow rapidly during the first two years of their lifespan and then the growth rate is reduced (Suzuki et al. 2002). The growth of turbots depends highly on environmental conditions, particularly temperature (Le Ruyet 2001) and food availability (Arneri et al. 2001).

In the Black Sea, the growth performance index ( $\left.\Phi^{\prime}\right)$ for turbots ranged between 6.49 and 7.28 (Ivanov and Beverton 1985, Erdem 1997, Zengin et al. 2005). In the present study, the estimated $\Phi$ ' value of tagged turbots (7.19) suggests that they are a good species for releasing. The condition factor values of recaptured fishes are expected to decline, reflecting the consumption of energy reserves without replacement. The same pattern has also been observed in the aquaculture-produced and released meagre Argyrosomus regius (Gil et al. 2014). The growth performance index estimations provide an indication of the reliability of estimates since it is suggested that growth performance index values are similar for the same species and genera.

\section{Migration}

Over half of the captures $(55.5 \%$ of the total caught fishes) had remained within $10 \mathrm{~km}$ of the area of release. The rest (44\%) were mostly caught between 10 and $100 \mathrm{~km}$, and only a few $(0.5 \%)$ were at a greater distance.

Turbots released in this study were well distributed throughout the southeastern Black Sea. The tagged turbots were characterized as "resident" or "migratory" according to their movement. Most of the individuals exhibited resident behaviour, while others moved westward or eastward from the area of release. Longdistance migrations of turbots were found in some cases. For example, captured turbots caught in the western (Espiye) and eastern (Hopa) regions (almost $135 \mathrm{~km}$ away from area of release 20 months earlier). Zengin et al. (2005) reported that the maximum migratory distance of tagged turbots is $200 \mathrm{~km}$ from the area of release and depended on fish behaviour and the flow route. In the southeastern Black Sea, there is a closed flow system from the Anatolian coast to Batumi (Oğuz et al. 1993). Other tagging studies have reported limited movements of turbots and other flatfishes. Støttrup et al. (2002) found short-distance movement of tagged turbots in Danish waters; $96 \%$ and $76 \%$ of individuals at ages 1 and 2, respectively, were caught within $10 \mathrm{~km}$ of the release site. Bagge (1987) also reported a very limited migration for larger turbots that were tagged and released in the central Kattegat. Like turbots, winter flounder (Pseudopleuronectes americanus) and plaice (Pleuronectes platessa) were recaptured close to the area of release (Saucerman and Deegan 1991, Burrows et al. 2004).

The same results for vertical distribution were pointed out by Suzuki et al. (2002) and Zengin et al. (2005). Yoseda et al. (2012) reported that wild turbots in the same area were distributed from 5 to $70 \mathrm{~m}$ depth, where bottom water temperatures ranged between $8^{\circ} \mathrm{C}$ and $26^{\circ} \mathrm{C}$. Water temperature was the most important factor for vertical distribution of turbots. The same au- 
thors reported that turbot specimens were found at 10 $\mathrm{m}$ during summer months and in deeper layers (5-60 $\mathrm{m})$ in winter. During the whole study period, however, turbots occupied mainly continental slope waters from about 20 to $90 \mathrm{~m}$. They appeared to undergo seasonal shifts in depth distribution, moving deeper in winter and shallower in summer. In addition to this, some researchers have reported that, during its vertical distribution, turbot reaches the deeper layers (120 and 137 $\mathrm{m}$ depth) for vertical distribution of turbot in the Black Sea (Slastenenko 1956, Karpetkova 1980).

Since the information about the vertical migration is important for the fishery and the bio-ecologic behaviours of turbot, horizontal migration could be considered as an important parameter for stock enhancement programmes, due mainly to the increased fishing activity of the artisanal fishery in the area. Knowledge of horizontal migration is also important for determining the administrative boundaries in terms of fisheries in the area of release (Zengin et al. 2005). In the present study area, however, the migration type and run timings of wild and hatchery turbot populations did not differ from each other.

\section{Feeding}

Most of the tagged fishes were caught by commercial turbot fisheries using bottom-set gillnet, with vessels usually remaining at sea for 7-10 days (Samsun et al. 2004). This may be the main reason for the increased ratio of the vacuity index.

The diet of turbots in this study was similar to that previously described by (Zengin 2000) for the wild population. The teleost fish group constitutes more than the $90 \%$ of total IRI and can be defined as the main food for the wild population of this species (Oñate 1989, Zengin et al. 2005, Panayotova and Todorova 2008, Sparrevohn and Støttrup 2008). Among fishes, Merlangius merlangius was also the most important prey item for turbot. In northwest Spain, young turbots fed on mysids, decapods and small fish, whereas larger individuals preferred fishes and decapods (Oñate 1989). The relationship between turbot length and diet size was also reported by (Jones 1970, Aarnio et al. 1996). Although there are differences in prey and feeding behaviour between wild and hatchery turbots (Person-Le Ruyet 2002), released hatchery turbots seem to be able to adapt to natural diet within a few weeks (Nielsen et al. 2004).

Turbot has a flattened body and its mouth is very large, suggesting that it prefers to consume benthic preys. In addition, turbot prefer pelagic fishes which may have nictemeral migrations. This result shows that turbots prefer to consume more active, moving and faster preys and this capability allows them to forage along the water column (Ebeling 1988, Farias et al. 2005).

\section{CONCLUSION}

The success of stock enhancement/restocking depends on the extent of knowledge in ecosystem dynamics and population dynamics of the species. The results of the present study showed that hatchery-released turbots may be a useful tool for enhancing stock in the Black Sea, because of their high growth rate, commercial value, and limited migration range. Turbot stock enhancement programmes in the Black Sea showed that a substantial number of released turbots (about $8 \%$ of the returned specimens) matured in the wild environment. Releases of hatchery turbot integrated in a resource management programme of sustainable fisheries and habitat restoration can successfully enhance fisheries recruitment.

\section{REFERENCES}

Aarnio K., Bonsdorff E., Rosenback N. 1996. Food and feeding habits of juvenile flounder Platichthys flesus (L.), and turbot Scophthalmus maximus L. in the A land archipelago, Northern Baltic Sea. J. Sea Res. 36: 311-320. http://dx.doi.org/10.1016/S0077-7579(96)90058-7

Anonymous. 2016. Turkish Fishery Regulation Circular (37/1) for Marine and Inland Commercial Fisheries in Fishing Season 2014-2016, (in Turkish). T.C. TKB-KKGM, R.G. Say1: 26269 Ankara, 108 pp.

Aneer G., Westin L. 1990. Migration of turbot (Psetta maxima L.) in the northern Baltic Proper. Fish. Res. 9: 307-315. http://dx.doi.org/10.1016/0165-7836(90)90049-2

Arneri E., Colella S., Giannetti G. 2001. Age determination and growth of turbot and brill in the Adriatic Sea: reversal of the seasonal pattern of otolith zone formation. J. Appl. Ichthyol. 17: 256-261. http://dx.doi.org/10.1046/j.1439-0426.2001.00293.x

Bagge O. 1987. Tagging of Turbot and Brill in the Kattegat 19651970. ICES, Demersal Fish Committee. C.M. 1987/G:10, 3 pp.

Bell J.D., Bartley D.M., Lorenzen K., et al. 2006. Restocking and stock enhancement of coastal fisheries: Potential, problems and progress. Fish. Res. 80: 1-8. http://dx.doi.org/10.1016/j.fishres.2006.03.008

Blanquer A., Alayse J.P., Rkhami B.O., et al. 1992. Allozyme variation in turbot (Psetta maxima) and brill (Scophthalmus rhombus) through their range in Europe. J. Fish. Biol. 41: 725-736. http://dx.doi.org/10.1111/j.1095-8649.1992.tb02702.x

Burrows M.T., Gibson R.N., Robb L., et al. 2004. Alongshore dispersal and site fidelity of juvenile plaice from tagging and transplants. J. Fish. Biol. 65: 620-634. http://dx.doi.org/10.1111/j.0022-1112.2004.00467.x

Çakmak E., Kurtoğlu İ.Z., Çavdar Y., et al. 2008. Karadeniz Alabalığı (Salmo trutta larax) yetiștiriciliği ve balıklandırma amacıyla kullanımı. Su Ürünleri Merkez Araştırma Enstitüsü. TAGEM/HAYSUD/2001/07/01/20, 204 pp.

Camp E.V., Lorenzen K., Ahrens R.N.M., et al. 2013. Potentials and Limitations of Stock Enhancement in Marine Recreational Fisheries Systems: An Integrative Review of Florida's Red Drum Enhancement. Rev. Fish. Sci. 21: 388-402. http://dx.doi.org/10.1080/10641262.2013.838075

Cortés E., Manire C.A., Hueter R.E. 1996. Diet, feding habits, and diel feeding chronology of the bonnethead shark, Sphyrna tiburo, in southwest Florida. Bull. Mar. Sci. 58: 353-367.

Cury P.M., Shin Y.J., Planque B. 2008. Ecosystem oceanography for global change in fisheries. Trends Ecol. Evol. 23: 338-346. http://dx.doi.org/10.1016/j.tree.2008.02.005

Delbare D., De Clerck R. 2000. Release of reared turbot in Belgian coastal waters as a tool for stock enhancement. Presentation of the paper ICES CM 2000/O:02 at the 2000 ICES Annual Science Conference, 28 September 2000.

Ebeling E. 1988. A brief survey of the feeding preferences of Raja clavata in Red Wharf Bay in the Irish Sea. ICES, Demers. Fish Commit. 1988/G, 58: 1-5.

Erdem Y. 1997. Karadeniz'de Avlanan Kalkan Balıklarının (Scopththalmus maximus) Galsama Ağları ile Seçiciliğinin Belirlenmesi. Doktora Tezi. Ondokuz Mayıs Ün. Fen Bilimleri Enst. Samsun, 64 pp.

Farias I., Figueiredo I., Sera-Pereire B., et al. 2005. Diet comparison of four ray species [Raja clavata Linnaeus, 1758; Raja brachyura Lafont, 1873; Leucoraja naevus (Müler \& Henle, 1841) and Raja montagui Fowler, 1910] caught along the Portuguese continental coast. Elasmobranch Fisheries Science, ICES CM 2005/N: 28. 
Genç Y., Mutlu C., Zengin M., et al. 2002 Doğu Karadeniz'deki Av Gücünün Demersal Balık Stokları Üzerine Etkisinin Tespiti, Tarım Köyişleri Bakanlığı, TAGEM, Trabzon Su Ürünleri Merkez Araştırma Enstitüsü, Sonuç Raporu, Proje No: TAGEM/IY/97/17/03/006, 114 pp.

Gil M.M., Palmer M., Grau A., et al. 2014. Adapting to the wild: The case of aquaculture-produced and released meagres Argyrosomus regius. J. Fish Biol. 84: 10-30. http://dx.doi.org/10.1111/jfb.12241

Gibson R.N. 1994. Impact of habitat quality and quantity on the recruitment of juvenile flatfishes. J. Sea Res. 32: 191-206. http://dx.doi.org/10.1016/0077-7579(94)90040-X

Giragosov V., Khanaychenko A. 2012. The State-of-Art of the Black Sea Turbot Spawning Population of Crimea (1998-2010). Turkish J. Fish. Aqu. Sci. 12: 377-383. http://dx.doi.org/10.4194/1303-2712-v12_2_25

Howell B.R. 1994. Fitness of hatchery-reared fish for survival in the sea. Aqu. Fish. Manag. 25: 3-17.

Holden M.J., Raitt D.F.S. 1974. Manual of fisheries science. Part 2. Methods of resource investigation and their application. FAO Fish. Tech. Pap. 115: 1-214.

Hyslop E.J. 1980. Stomach content analysis. A review of methods and their application. J. Fish Biol. 17: 411-429. http://dx.doi.org/10.1111/j.1095-8649.1980.tb02775.x

Ireland S.C., Siple J.T., Beamesderfer R.C.P., et al. 2002. Success of hatchery-reared juvenile white sturgeon (Acipenser transmontanus) following release in the Kootenai River. Idaho. J. Appl. Ichthyol. 18: 642-650. http://dx.doi.org/10.1046/j.1439-0426.2002.00364.x

Ivanov L., Beverton R.J.H. 1985. The fisheries resources of the Mediterranean and Black Sea. Etud Rev Part 2 CGPM/Stud Rev 60 GFCM $135 \mathrm{pp}$

Jones A. 1970. Some aspects of the biology of the turbot (Scophthalmus maximus L.) with special reference to feeding and growth in the juvenile stage. Ph.D. Thesis, Univ. East Anglia, 123 pp.

Jones R. 1976. The use of marking data in population analysis. FAO Fish Tech. Pap. 153: 42 pp.

Karpetkova M. 1980. Distribution and Migration of the Turbot Along the Bulgarian Coast of the Black Sea. Bull. Inst. Zool. et Musee, Tome XVI (In Bulgarian).

Kim K.W., Kim S.S., Khosravi S., et al. 2014. Evaluation of Sargassum fusiforme and Ecklonia cava as Dietary Additives for Olive Flounder (Paralichthys olivaceus). Turkish J. Fish. Aquat. Sci. 14: 321-330. http://dx.doi.org/10.4194/1303-2712-v14_2_03

Krumme U. 2009. Diel and Tidal Movements by Fish and Decapods Linking Tropical Coastal Ecosystems, In: Nagelkerken I., Ecological Connectivity among Tropical Coastal Ecosystems, Springer, London, pp. 271-324. http://dx.doi.org/10.1007/978-90-481-2406-0 8

Leber K.M., Cantrell R.N., Leung P.S. 2005. Optimizing cost effectiveness of size at release in stock enhancement programs. North Amer. J. Fish. Manag. 25: 1596-1608. http://dx.doi.org/10.1577/M04-093.1

Le Ruyet J.P. 2001. Turbot (Scophthalmus maximus) Grow-out in Europe: Practices, Results, and Prospects. Turkish J. Fish. Aquat. Sci. 2: 29-39. http://www.trjfas.org/uploads/pdf_247.pdf

Lejeusne C., Chevaldonné P., Pergent-Martini C., et al. 2010. Climate change effects on a miniature ocean: the highly diverse, highly impacted Mediterranean Sea. Trends Ecol. Evol. 25: 250-260. http://dx.doi.org/10.1016/j.tree.2009.10.009

Lorenzen K., Beveridge M.C.M., Mangel M. 2012. Cultured fish: Integrative biology and management of domestication and interactions with wild fish. Biol. Rev. 87: 639-660. http://dx.doi.org/10.1111/j.1469-185X.2011.00215.x

Lotze H.K., Lenihan H.S., Borque B.J., et al. 2006. Depletion, Degradation, and Recovery Potential of Estuaries and Coastal Seas. Science, 312: 1806-1809.

http://dx.doi.org/10.1126/science.1128035

Lv H., Zhang X., Zhang P., et al. 2011. The implement of plastic oval tags for mark-recapture in juvenile Japanese flounder (Paralichthys olivaceus) on the northeast coast of Shandong Province, China. African J. Biotech. 10: 13263-13277. http://www.ajol.info/index.php/ajb/article/view/96543

McFarlane G.A, Wydoski R.S., Winans G.A. 1990. External tags and marks. Amer. Fish. Soc. Symp. 7: 9-29.

Mengi T. 1971. Flatfish and their population in Turkish Seas. Bull. Sci. Faculty B 1-2: 53-70 (in Turkish).
Munro J.L., Bell J.D. 1997. Enhancement of marine fisheries resources. Rev. Fish. Sci. 5: 185-222. http://dx.doi.org/10.1080/10641269709388597

Nielsen E.E., Nielsen P.H., Meldrup D. et al. 2004. Genetic population structure of turbot (Scophthalmus maximus L.) supports the presence of multiple hybrid zones for marine fi shes in the transition zone between the Baltic Sea and the North Sea. Mol. Ecol. 13: 585-595. http://dx.doi.org/10.1046/j.1365-294X.2004.02097.x

Oğuz T., Latun V.S., Latif M.A., et al. 1993. Circulation in the surface and intermediate layers of the Black Sea. Deep-Sea Res. I. 40: $1597-1612$. http://dx.doi.org/10.1016/0967-0637(93)90018-X

Oñate F.C. 1989. The summer food of turbot Psetta maxima (L.) of the Coast of Galicia, N.W. Spain. Ophelia 30: 21-33. http://dx.doi.org/10.1080/00785326.1989.10430833

Panayotova M.D., Todorova V.R. 2008. Stocks, Distribution and Population Parameters of Turbot (Psetta maxima L.) in front of the Bulgarian Black Sea Coast in 2006. Acta Zool. Bulg. Suppl. 2: $317-324$

Panayotova M.D., Raykov S.V., Todorova V.R. 2012. Turbot (Psetta maxima L.) Abundance Indices and Stock Dynamics of Bulgarian Black Sea Coast During the Period 2006-2009. Acta Zool. Bulg. 64: 85-91.

Pauly D., Munro J.L. 1984. Once more on the comparison of growth in fishes and invertebrates. ICLARM Fishbyte 2: 2-21.

Person-Le Ruyet J. 2002. Turbot (Scophthalmus maximus) growout in Europe: practices, results, and prospects. Turkish J. Fish. Aqua. Sci. 2: 29-39

Samsun O. 1995. Orta Karadeniz'de 1992-1994 Su Ürünleri Av Döneminde Dip Trolleri ile Avlanan Kalkan (Scopthalmus maeoticus) Balığının Av Kompozisyonu Üzerine Bir Araştırma. Süleyman Demirel Ün Eğridir Su Ürünleri Fak. Dergisi 4: 227-233.

Samsun N., Kalayc1 F., Samsun O. 2004. The determination of turbot tangle nets and trammel nets features, catch per unit effort (CPUE) and turbot fishing in Middle Black Sea (Sinop). Eğirdir Su Ürünleri Fakültesi Dergisi, Cilt II, Say1, XII, 99-108 (in Turkish)

Saucerman S.E, Deegan L.A. 1991. Lateral and cross-channel movements of young-of-the-year winter flounder (Pseudopleuronectes americanus) in Waquiot Bay, Massachusetts. Estuaries 14: 440-446. http://dx.doi.org/10.2307/1352268

Slastenenko E. 1956. Karadeniz Havzası Balıkları. Rusça'dan çeviren; Altan, H.,E. EKB Umum Müdürlüğüü, İstanbul, 711 pp.

Sogard S.M., Able K.W. 1992. Growth variation of newly settled winter flounder (Pseudopleuronectes americanus) in New Jersey estuaries as determined by otolith microstructure. Netherlands J. Sea Res. 29: 163-172. http://dx.doi.org/10.1016/0077-7579(92)90017-9

Sparre P., Venema S.C. 1992. Introduction to Tropical Fish Stock Assessment. Part I, FAO Fish. Tech. Pap. No: 306/1, Rev. 1, Rome, $376 \mathrm{pp}$

Sparrevohn C.R., Støttrup J.G. 2008. Diet, Abundance, and Distribution as Indices of Turbot (Psetta maxima L.) Release Habitat Suitability. Rev. Fish. Sci. 16: 338-347. http://dx.doi.org/10.1080/10641260701686846

STECF. 2014. Scientific, Technical and Economic Committee for Fisheries (STECF). Black Sea Assessment (STCEF 14-14). Ed. David Sampson, Dimitrios Damalas \& Chato Osio. 421 pp. ISSN 1831-9424. http://dx.doi.org/10.2788/19168

Støttrup J.G., Sparrevohn C.R., Modin J., et al. 2002. The use of releases of reared fish to enhance natural populations: A case study on turbot Psetta maxima. Fish. Res. 1361: 1-20. http://dx.doi.org/10.1016/s0165-7836(01)00413-1

Suzuki N., Kondo M., Güneş E., et al. 2002. Age and Growth of Turbot, Psetta maxima in the Black Sea, Turkey. Turkish J. Fish. Aquat. Sci. 2: 43-51.

Thorstad E.B., Rikardsen A.H., Alp A., et al. 2013. The Use of Electronic Tags in Fish Research - An Overview of Fish Telemetry Methods. Turkish J. Fish. Aquat. Sci. 13: 881-896. http://dx.doi.org/10.4194/1303-2712-v13 513

Thorsteinsson V., Arnold G., Davenport J., et al. 2002. Tagging methods for stock Assessmentand research in Fisheries. Report of Concerted Action FAIR CT.96.1394 (CATAG) 186 pp.

TUIK. 2014. Fishery statistics from 2000 to 2014, TUIK published, Ankara (in Turkish).

Turek J., Horký P., Žlábek V., et al. 2012. Recapture and condi- 
tion of pond-reared, and hatchery-reared 1+ European grayling stocked in addition to wild conspecifics in a small river. Knowl. Manag. Aquat. Ecosyst. 405: 10.

http://dx.doi.org/10.1051/kmae/2012016

Üstündağ C. 2003. Seed Production of turbot, Psetta maxima. CFRI YUNUS Res. Bull. 3: 6-11.

Üstündağ C., Çiftçi Y., Sakamato F. 2002. Rearing of larvae and juveniles of Black Sea turbots, Psetta maxima, in Turkey. Turkish J. Fish. Aquat. Sci. 2: 13-17.

Yamashita T, Yamada H. 1999. Marine enhancement and sea ranching: Release strategy for Japanese flounder fry in stock enhancement programs. Oxford, New York, pp. 191-204.

Yoseda K., Sahin T., Üstündağ C., et al. 2012. Seasonal distribution and migration pattern of the turbot Psetta maxima in the Eastern Black Sea, Republic of Turkey. Yunus Arastırma Bülteni 1: 20-28.

Zar J.H. 1996. Biostatistical Analysis. Prentice-Hall, Eryelwood Cliffs, N.J. 663 pp.
Zengin M. 2000. The bioecology and population parameters of the turbot (Scophthalmus maeoticus Pallas, 1811) in the Turkish coast of the eastern Black Sea. PhD Thesis, KTÜ, $221 \mathrm{pp}$.

Zengin M., Polat H., Kutlu S., et al. 2005. Yetiştiricilik Yoluyla Uretilen Kalkan Balığı Yavrularının Doğal Stoka Katılımları ve Biyoekolojik Özelliklerinin İncelenmesi (2000-2005). Su Ürünleri Merkez Araştırma Enstitüsü Müdürlüğü. TAGEM/ HAYSÜD/2000/17/03/010.

Zengin M., Dağtekin M., Türe M. 2015. Doğal Populasyonları Iyileştirme Amacı ile Yeşilırmak, Kızılırmak ve Sakarya Nehirlerine Bırakılan Kültür Orijinli Markalı Yavru Mersin Balıklarının (Acipencer stellatus ve Acipencer gueldenstaedti) Denizel Ortamdaki Göç ve Büyümelerinin Takibi. II. Balıklandırma ve Rezervuar Yönetimi Sempozyumu, 20-22 Mayıs 2015. Eğirdir Su Ürünleri Araștırma İstasyonu Müdürlüğü. Bildiri Özetleri Kitab1, 116 pp. 